\title{
Studies on N-metabolism in different gastro- intestinal sections of sheep using the digesta exchange technique. 2. Passage of endogenous nitrogen $^{*}$
}

\section{A. Sandek ${ }^{1}$, K. Krawielitzki², J. Kowalczyk ${ }^{3}$, F. Kreienbring ${ }^{2}$, U. Schönhusen ${ }^{4}$, M. Gabel', T. Żebrowska ${ }^{3}$, H. Hagemeister ${ }^{4}$ and $\mathrm{J}$. Voigt ${ }^{4,5}$}

\author{
'Institute for Ecological-Compatible Animal Husbandry, University of Rostock \\ Justus-von-Liebig-Weg 8, 18059 Rostock, Germany \\ 'Institute for Applied Agroecology \\ Justus-von-Liebig-Weg 8, 18059 Rostock, Germany \\ ${ }^{3}$ The Kielanowski Institute of Animal Physiology and Nutrition, \\ Polish Academy of Sciences \\ 05-110 Jablonna, Poland \\ "Research Institute for the Biology of Farm Animals, \\ Research Unit Nutritional Physiologv "Oskar Kellner" \\ Wilhelm-Stahl-Allee 2,18196 Dummerstorf. Germany
}

(Received 2 July 2001; accepted 6 November 2001)

\section{ABSTRACT}

Using a combination of fistulation and the ${ }^{15} \mathrm{~N}$ isotope tcchnique, the flow rates of endogenous $\mathrm{N}$ secreted postruminal into different sections of the digestive tract were estimated in growing sheep by digesta exchange between ${ }^{15} \mathrm{~N}$-labelled and unlabelled animals. To investigate the influence of fibre (CF) on these flow rates the estimations were made on two groups that received approximately isonitrogenous diets (16\% CP in DM ) differing in crude fibre content (Group 1: 14.7\%, Group 2: $24.9 \%$ CF in DM).

\footnotetext{
- Supported by the Deutsche Forschungsgemeinschaft (DFG), the H. Wilhelm Schaumann Stiftung and by the Polish State Committec for Scientific Research

5 Corresponding author
} 
The passage rates of total $\mathrm{N}$ and ${ }^{15} \mathrm{~N}$ at the duodenum and ileum and the excretion in faeces were measured directly. These data were used to calculate the passage of postruminal $\mathrm{N}$ secreted in the different intestina! sections. The microbial $N$ passage at the proximal duodenum and distal ileum was calculated as the product of RNA passage at the duodenum and ileum, and the N:RNA ratio of bacteria isolated from rumen fluid. The flow rates of endogenous $\mathrm{N}$ into the duodenum and through the ileum and the excretion rate in faeces were estimated by measuring the appearance and disappearance rates of ${ }^{15} \mathrm{~N}$ in appropriate intestinal sections of the unlabelled animals receiving ${ }^{15} \mathrm{~N}$-labelled digesta or in the labelled animals getting unlabelled digesta by digesta exchange.

The microbial flow rate through the duodenum was in average $5.8 \mathrm{~g} \mathrm{~N} / \mathrm{d}$ in Group 1 and $5.1 \mathrm{~g} \mathrm{~N} / \mathrm{d}$ in Group 2 ( 50 and $46 \%$ of NAN flux), and $0.9 \mathrm{~g} \mathrm{~N} / \mathrm{d}$ (Group 1) to $1.3 \mathrm{~g} \mathrm{~N} / \mathrm{d}$ (Group 2) through the ileum ( 19 and $22 \%$ of NAN flux). The portion of rumen undegraded protein-N of NAN flow was in Group $147 \%$ both in the duodenum and in the ileum. In Group 2 it was $42 \%$.

The endogenous NAN entering the duodenum was low for Group $1(0.40 \mathrm{~g} \mathrm{~N} / \mathrm{d}=3.4 \%$ of NAN) and approximately three-fold higher for Group $2(1.3 \mathrm{~g} \mathrm{~N} / \mathrm{d}=12 \%$ of NAN). The corresponding values for endogenous $\mathrm{N}$ at the ileum were $1.6 \mathrm{~g} / \mathrm{d}(34 \%$ of NAN) and $2.2 \mathrm{~g} / \mathrm{d}$ ( $36 \%$ of NAN), indicating that in relative terms, endogenous $\mathrm{N}$ secretion in this section of the digestive tract was independent of the feeding regime.

The excretion rate of endogenous $\mathrm{N}$ in faeces varied between the individual experiments ( 1.84 to $2.39 \mathrm{~g} \mathrm{~N} / \mathrm{d}$ for Group $1 ; 1.54$ to $2.00 \mathrm{~g} \mathrm{~N} / \mathrm{d}$ for Group 2). In relation to total faecal N excretion the endogenous fraction was higher for Group $1(56 \%)$ than for Group $2(40 \%)$.

During all of the experiments, endogenous $\mathrm{N}$ as a proportion of total $\mathrm{N}$ increased from the duodenum to the rectum. Despite some reservations about the ${ }^{15} \mathrm{~N}$ dilution method, its use together with the technique of digesta exchange between labelled and unlabelled animals is a potentially useful way to quantify the passage of postruminal secreted $\mathrm{N}$ in dependence of nutritional factors. Further studies are needed to refine the methodology.

KEY WORDS: sheep, digestive tract, digesta exchange, ${ }^{15} \mathrm{~N}$, endogenous $\mathrm{N}$, microbial $\mathrm{N}$, crude fibre

\section{INTRODUCTION}

In addition to the estimation of flow rates for total $\mathrm{N}$ through the small intestine, information on endogenous $\mathrm{N}$ is required for exact determination of the true digestibility of $\mathrm{N}$ in the digestive tract. Quantifying $\mathrm{N}$ secretion and reabsorption in ruminants is difficult because the $\mathrm{N}$ flow into the duodenum consists of dietary protein, microbial protein and endogenous N. Additionally it should be considered that the ruminal microbial $\mathrm{N}$ originates from exogenous and endogenous sources. As reported by Sandek et al. (2001) the technique of digesta exchange between animals in combination with the isotope dilution technique can be used to differentiate between various $\mathrm{N}$ sources in the gastrointestinal tract of ruminants.

Following the estimation of digesta and $\mathrm{N}$ flow rates at the duodenum and ileum, and of excretion rates in faeces of growing sheep fed diets differing in crude fibre content (Sandek et al., 2001), the present paper deals with the calculation of the passage of postruminal secreted $\mathrm{N}$ in the duodenum, ileum and faeces. 


\section{MATERIAL AND METHODS}

\section{Animals, procedures and diets}

Two groups of male growing Polish Merino sheep ( $20-25 \mathrm{~kg}$ body weight) were fitted with a cannula into the rumen, with re-entrant cannulas in the proximal duodenum and distal ileum and with a jugular vein catheter. One of the three sheep (animal No. 1) was infused intraruminally with ${ }^{15} \mathrm{~N}$ urea to label the metabolic $\mathrm{N}$ pool. After $6 \mathrm{~d}$ of labelling the duodenal and the ileal digesta were exchanged between the labelled animal and the unlabelled ones according to the scheme below.

Duodenal cannulas:

from animal No. 1 ( ${ }^{15} \mathrm{~N}$-labelled) $\Rightarrow$ animal No. 2 (unlabelled)

from animal No. 2 (unlabelled) $\Rightarrow$ animal No. 3 (unlabelled)

from animal No. 3 (unlabelled) $\Rightarrow$ animal No. 1 ( ${ }^{15} \mathrm{~N}$-labelled).

Ileal cannulas:

from animal No. 1 ( ${ }^{15} \mathrm{~N}$-labelled) $\Rightarrow$ animal No. 3 (unlabelled)

from animal No. 3 (unlabelled) $\Rightarrow$ animal No. 1 ( ${ }^{15} \mathrm{~N}$-labelled)

from animal No. 2 (unlabelled) $\Rightarrow$ animal No. 2 (unlabelled).

In order to investigate the influence of crude fibre on $\mathrm{N}$ digestion, two dietary treatments were used. The diets were approximately isonitrogenous but differed in crude fibre content:

Group 1: Experiments 1 to 3 with low fibre (CF) content in the ration $(14.7 \%$ CF/DM; 16.3\% CP/DM; $11 \mathrm{MJ}$ ME/kg DM; $616 \mathrm{~g} \mathrm{DM} \mathrm{intake/d} \mathrm{)}$

Group 2: Experiments 4 to 6 with high $\mathrm{CF}$ content in the ration $(24.9 \% \mathrm{CF} /$ $\mathrm{DM} ; 15.7 \% \mathrm{CP} / \mathrm{DM} ; 10 \mathrm{MJ} \mathrm{ME} / \mathrm{kg} \mathrm{DM} ; 467 \mathrm{~g} \mathrm{DM}$ intake/d).

Further details of experimental conditions and procedures are presented by Sandek et al. (2001). Additionally, ammonia was estimated as described by Voigt and Steger (1967). The method of Schönhusen et al. (1988) was used for detcrmination of RNA.

\section{Calculations}

$N$ and ${ }^{15} N$ flow rates. The amount of the daily total $\mathrm{N}$ passage $(\mathrm{g})$ into duodenal and ileal fistulas as well as faecal $\mathrm{N}$ excretion were measured directly during a $48 \mathrm{~h}$ digesta exchange period between ${ }^{15} \mathrm{~N}$-labelled and unlabelled animals. The ${ }^{15} \mathrm{~N}$ flow rates $(\mathrm{g} / \mathrm{d})$ were calculated as the product of $\mathrm{N}$ passage rate and ${ }^{15} \mathrm{~N}$ at $\%$ excess (all ${ }^{15} \mathrm{~N}$ values are excess values) of the digesta and faeces according to the following equation:

$$
{ }^{15} \mathrm{~N}[\mathrm{~g} / \mathrm{d}]=\frac{\mathrm{N}[\mathrm{g} / \mathrm{d}] \times{ }^{15} \mathrm{~N}[\mathrm{at} \%] \times 15}{1400}
$$


As an example, the $\mathrm{N}$ and ${ }^{15} \mathrm{~N}$ flow rates for Experiment 5 are given in Table 1 .

The ${ }^{15} \mathrm{~N}$ passage at the duodenum of both animals No 2 and No 3, which were unlabelled at the beginning of the exchange period, demonstrates clearly that these animals will be labelled too by ${ }^{15} \mathrm{~N}$ during the exchange period. This labelling arises from the administration of ${ }^{15} \mathrm{~N}$-labelled digesta of animal No 1 into the caudal duodenal fistula of animal No 2 and into the ileal fistula of animal No 3. Thus ${ }^{15} \mathrm{~N}$ is absorbed during the digesta passage through the intestinal section (duodenum - rectum) and following rumeno-hepatic recycling of the absorbed ${ }^{15} \mathrm{~N}$.

TABLE 1

$\mathrm{N}$ and ${ }^{15} \mathrm{~N}$ passage at the duodenum and ileum, excretion with faeces and urine and ${ }^{15} \mathrm{~N}$ enrichment in TCA soluble plasma and rumen microbes for experiment 5 (Group 2)

\begin{tabular}{|c|c|c|c|c|c|c|c|}
\hline & \multicolumn{2}{|c|}{ Animal No. 3} & \multicolumn{2}{|c|}{$\begin{array}{l}\text { Animal No. } 1 \\
{ }^{15} \mathrm{~N} \text { labelled }\end{array}$} & \multicolumn{2}{|c|}{ Animal No. 2} & \multirow{2}{*}{$\begin{array}{c}\begin{array}{c}\text { Total } \\
\text { Mean } \pm \text { SD }\end{array} \\
\text { N } \\
\text { g/d }\end{array}$} \\
\hline & $\begin{array}{l}\mathrm{N} \\
\mathrm{g} / \mathrm{d}\end{array}$ & $\begin{array}{l}{ }^{15} \mathrm{~N} \\
\mathrm{mg} / \mathrm{d}\end{array}$ & $\begin{array}{l}\mathrm{N} \\
\mathrm{g} / \mathrm{d}\end{array}$ & $\begin{array}{l}{ }^{15} \mathrm{~N} \\
\mathrm{mg} / \mathrm{d}\end{array}$ & $\begin{array}{l}\mathrm{N} \\
\mathrm{g} / \mathrm{d}\end{array}$ & $\begin{array}{l}{ }^{15} \mathrm{~N} \\
\mathrm{mg} / \mathrm{d}\end{array}$ & \\
\hline $\mathrm{N}$ intake & 11.05 & 0 & 10.48 & 460.4 & 11.72 & 0 & $11.72 \pm 0.63$ \\
\hline $\begin{array}{l}\mathrm{N} \text { outflow of the } \\
\text { duodenal fistula }\end{array}$ & 11.88 & 1.59 & 12.81 & 270.9 & 13.77 & 12.53 & $12.82 \pm 0.95$ \\
\hline Re-entrance $(-3 \%)$ & $\perp^{13.36}$ & 12.15 & 11.52 & $\stackrel{1.54}{\downarrow}$ & 1 & $\frac{261.8}{1}$ & $12.44 \pm 0.92$ \\
\hline $\begin{array}{l}N \text { outflow of the ileal } \\
\text { fistula }\end{array}$ & 6.47 & 3.90 & 6.19 & 20.05 & 6.40 & 105.1 & $6.35 \pm 0.15$ \\
\hline Re-entrance $(-3 \%)$ & $\frac{6.00}{1}$ & $\perp^{19.45}$ & $\frac{6.28}{\downarrow}$ & $\begin{array}{c}3.78 \\
1\end{array}$ & $\frac{6.21}{1}$ & $\frac{1}{1}$ & $6.16 \pm 0.15$ \\
\hline $\begin{array}{l}\mathrm{N} \text { in faeces } \\
\mathrm{N}_{\text {corrected }} \text { in faeces }\end{array}$ & $\begin{array}{l}3.60 \\
3.87\end{array}$ & $\begin{array}{l}5.51 \\
5.92\end{array}$ & $\begin{array}{l}5.16 \\
3.47\end{array}$ & $\begin{array}{l}22.13 \\
14.88\end{array}$ & $\begin{array}{l}5.08 \\
4.12\end{array}$ & $\begin{array}{l}56.09 \\
45.49\end{array}$ & $\begin{array}{l}4.61 \pm 0.88 \\
3.82 \pm 0.33\end{array}$ \\
\hline $\mathrm{N}$ in urine & 9.81 & 9.52 & 7.75 & 177.3 & 8.02 & 61.66 & $8.53 \pm 1.12$ \\
\hline $\begin{array}{l}{ }^{15} \mathrm{~N} \text { at } \% \text { excess in: } \\
\mathrm{TCA} \text { soluble plasma } \\
\text { rumen microbes }\end{array}$ & & & & & $\begin{array}{l}0.2 \\
0.0\end{array}$ & & - \\
\hline
\end{tabular}

1 animals No. 1, 2, 3 
These $\mathrm{N}$ and ${ }^{15} \mathrm{~N}$ flow rates provided the basis for calculating the postruminal secretion of $\mathrm{N}$. Since the $\mathrm{NH}_{3}-\mathrm{N}$ secreted by the rumeno-hepatic recycling and the microbial endogenous $\mathrm{N}$ should not be included in the calculation of the postruminal secreted $\mathrm{N}$, the estimated ${ }^{15} \mathrm{~N}$ flow rates were corrected for the passage of microbial $\mathrm{N}$ and $\mathrm{NH}_{3}-\mathrm{N}$.

Passage of microbial $N$. For the estimation of the microbial $N$ passage to the proximal duodenum and terminal ileum, bacteria were isolated from rumen juice. The N:RNA ratio of these isolated bacteria amounted to 1.41 and in combination with the RNA passage rate of digesta the microbial N passage was calculated (Equation 2).

$$
\text { Microbial } \mathrm{N}[\mathrm{g} / \mathrm{d}]=\text { RNA-passage }[\mathrm{g} / \mathrm{d}] \times \mathrm{N} \text { : RNA in bacteria }
$$

The microbial $\mathrm{N}$ passage rates for the duodenum and ileum are given in Table 2.

The estimated $\mathrm{N}$ and ${ }^{15} \mathrm{~N}$ flow rates of the duodenal and ileal digesta and of ${ }^{15} \mathrm{~N}$ excess of the TCA soluble blood plasma $\mathrm{N}$ together with the passage rates of microbial $\mathrm{N}$ in the duodenum and ileum are the basis for calculating the endogenous $\mathrm{N}$ fraction (not microbial bound) of the total $\mathrm{N}$ flow rates.

Flow rate of endogenous $N$ into the duodenum. Using the amount of microbial $\mathrm{N}$ in the duodenal and ileal digesta (Table 2 ) and the ${ }^{15} \mathrm{~N}$ excess estimated in isolated rumen microbes of animal No. 2 (example from Experiment 5 in Table 1) it is possible to calculate the microbial fraction of the ${ }^{15} \mathrm{~N}$ digesta (Equation 1) and then the fraction of endogenous ${ }^{15} \mathrm{~N}$ (difference between total ${ }^{15} \mathrm{~N}$ in the digesta and ${ }^{15} \mathrm{~N}$ amount from microbes; Equation 3).

Endogenous ${ }^{15} \mathrm{~N}$ in digesta $[\mathrm{mg} / \mathrm{d}]=$ total ${ }^{15} \mathrm{~N}[\mathrm{mg} / \mathrm{d}]-\operatorname{microbial}{ }^{15} \mathrm{~N}[\mathrm{mg} / \mathrm{d}]$

Assuming that the ${ }^{15} \mathrm{~N}$ at \% excess of endogenous $\mathrm{N}$ and of the TCA soluble $\mathrm{N}$ fraction of the plasma is identical (Lammers-Wienhoven et al., 1998), the amounts of endogenous $\mathrm{N}$ passing the duodenum and the ileum can be estimated as follows:

$$
\text { Endogenous } \mathrm{N}[\mathrm{g} / \mathrm{d}]=\frac{\text { endogenous }{ }^{15} \mathrm{~N} \text { in digesta }[\mathrm{mg} / \mathrm{d}] \times 14}{150 \times{ }^{15} \mathrm{~N} \text { in TCA soluble plasma } \mathrm{N}[\text { at } \%]}
$$

The estimation of flow rates of endogenous $\mathrm{N}$ into the duodenum was not possible for labelled animal No. 1 , since the ${ }^{15} \mathrm{~N}$ present in its duodenal digesta consisted of infused urea ${ }^{15} \mathrm{~N}$ and ${ }^{15} \mathrm{~N}$ of endogenous origin. Because of the different ${ }^{15} \mathrm{~N}$ levels of these sources a distinction was not possible. This problem shows clearly the necessity for digesta exchange between labelled and unlabelled animals. 
In contrast with animal No. 1 , the estimation of the flow rates of endogenous $\mathrm{N}$ into the duodenum of animal No. 2 was possible. This animal received no ${ }^{15} \mathrm{~N}$-infusion, but got ${ }^{15} \mathrm{~N}$-labelled duodenal digesta coming from animal No. 1. This ${ }^{15} \mathrm{~N}$ was partly absorbed and then secreted by rumeno-hepatic recycling. Therefore all ${ }^{15} \mathrm{~N}$ found in the duodenal digesta of animal No. 2 must be of endogenous origin. The relative flow rate of endogenous $\mathrm{N}$ (\% of total $\mathrm{N}$ flow) of animal No. 2 was then applied to the mean value of total $\mathrm{N}$-flow rate for all three animals.

For calculation of the endogenous $\mathrm{N}$ flowing into the duodenum, $\mathrm{N}$ secretion in bile and by the pancreas had to be taken into consideration because the duodenal fistula was positioned caudally to the bile and pancreatic duct. Thus the duodenal digesta included these secretions (Sandek et al., 2001).

Additionally, for calculation of the endogenous NAN flow into the duodenum, a correction for $\mathrm{NH}_{3}-\mathrm{N}$ was necessary. The $\mathrm{NH}_{3}$-portion of total $\mathrm{N}$ in duodenal digesta amounted to $5.3 \%$ for both feeding groups (treatments).

Endogenous NAN duod. $[\mathrm{g} / \mathrm{d}]=$
$\quad$ endogenous $\mathrm{N}_{\text {duod. }}[\mathrm{g} / \mathrm{d}]-\mathrm{NH}_{3}-\mathrm{N}_{\text {dwod. }}[\mathrm{g} / \mathrm{d}]-\mathrm{N}_{\text {in bile and pancreas secrets }}[\mathrm{g} / \mathrm{d}]$

The calculated flow rates of endogenous $\mathrm{N}$ into the duodenum are shown in Table 2.

Flow rate of endogenous $N$ through the ileum. The endogenous $\mathrm{N}$ flow through the ileum consists of two components:

1. the endogenous $\mathrm{N}$ secreted but not reabsorbed in the small intestine (between the duodenal and ileal fistula). This consists predominantly of protein- and urea-N (Net $\mathrm{N}$ secretion)

2. the undigested residues of endogenous $\mathrm{N}$ flowing into the duodenum including bile- and pancreatic-N.

The two parts of endogenous $\mathrm{N}$ could not be estimated on the same animal. The first part, the Net $\mathrm{N}$ secretion into the small intestine, was determined using animal No. 1. This animal was ${ }^{15} \mathrm{~N}$-labelled and got unlabelled duodenal digesta from animal No. 3. Therefore all ${ }^{15} \mathrm{~N}$ measured in the ileal digesta was of endogenous origin and had been secreted during passage through this section.

Assuming that the ${ }^{15} \mathrm{~N}$ excess of endogenous $\mathrm{N}$ and of the TCA-soluble fraction of the plasma is identical, the Net $\mathrm{N}$ secretion results from the difference of measured ${ }^{15} \mathrm{~N}$ in ileal and duodenal digesta and of the measured ${ }^{15} \mathrm{~N}$ excess in TCAsoluble plasma of animal No. 1 . The taking of $3 \%$ digesta for analysis was accounted for by using a factor of 1.03 .

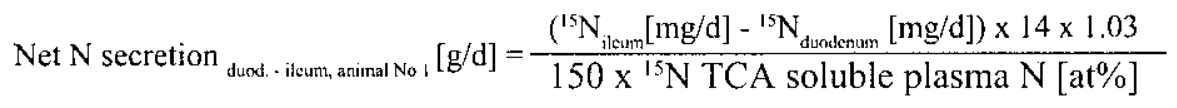


TABLE 2

Flow rates of endogenous $\mathrm{N}$ and rumen undegraded $\mathrm{N}$ at the duodenum and ileum and excretion rates in faeces

\begin{tabular}{|c|c|c|c|c|}
\hline & \multicolumn{2}{|c|}{$\begin{array}{c}\text { Group } 1(\mathrm{n}=2) \\
\text { CF intake: } 89.7 \mathrm{~g} / \mathrm{d} \\
\text { DM intake: } 616 \mathrm{~g} / \mathrm{d}\end{array}$} & \multicolumn{2}{|c|}{$\begin{array}{c}\text { Group } 2(\mathrm{n}=3) \\
\text { CF intake: } 116.4 \mathrm{~g} / \mathrm{d} \\
\text { DM intake: } 467 \mathrm{~g} / \mathrm{d}\end{array}$} \\
\hline & $\mathrm{g} / \mathrm{d}$ & $\%$ of NAN & $\mathrm{g} / \mathrm{d}$ & $\%$ of NAN \\
\hline Total N-intake & 16.10 & & 11.70 & \\
\hline \multicolumn{5}{|c|}{ Flow into the duodenum } \\
\hline Total N & $12.21 \pm 0.96$ & & $11.62 \pm 2.01$ & \\
\hline NAN & $11.44 \pm 0.90$ & & $10.96 \pm 1.90$ & \\
\hline Endogenous $\mathrm{N}$ & $0.40 \pm 0.04$ & $3.4 \pm 0.1$ & $1.34 \pm 0.18$ & $12.3 \pm 1.3$ \\
\hline Microbial $\mathrm{N}$ & $5.76 \pm 0.61$ & $50.2 \pm 1.2$ & $5.06 \pm 0.67$ & $46.4 \pm 3.4$ \\
\hline Undegraded $\mathrm{N}$ & $5.29 \pm 0.25$ & $46.3 \pm 1.4$ & $4.56 \pm 1.2$ & $41.2 \pm 3.7$ \\
\hline \multicolumn{5}{|c|}{ Flow through the ileum } \\
\hline Total N & $5.14 \pm 0.46$ & & $6.32 \pm 0.87$ & \\
\hline NAN & $4.92 \pm 0.44$ & & $6.06 \pm 0.84$ & \\
\hline Endogenous $\mathrm{N}$ & $1.64 \pm 0.37$ & $33.8 \pm 11.0$ & $2.18 \pm 0.28$ & $36.1 \pm 2.2$ \\
\hline Microbial N & $0.93 \pm 0.18$ & $18.8 \pm 2.0$ & $1.32 \pm 0.26$ & $21.8 \pm 2.1$ \\
\hline Undegraded $\mathrm{N}$ & $2.35 \pm 0.63$ & $47.4 \pm 8.5$ & $2.55 \pm 0.44$ & $42.1 \pm 3.9$ \\
\hline \multicolumn{5}{|c|}{ Excretion by faeces } \\
\hline Total N & $3.78 \pm 0.17$ & & $4.42 \pm 0.63$ & \\
\hline Endogenous $\mathrm{N}$ & $2.12 \pm 0.39$ & $\begin{array}{r}56.0 \% \pm 7.8 \\
(\text { of total } \mathrm{N} \text { ) }\end{array}$ & $1.74 \pm 0.24$ & $\begin{array}{r}40.0 \% \pm 9.7 \\
(\text { of total } \mathrm{N})\end{array}$ \\
\hline
\end{tabular}

The second part of endogenous $\mathrm{N}$ in ileal digesta was calculated using animal No. 3. This animal was unlabelled and received ${ }^{15} \mathrm{~N}$-labelled digesta from animal No. 1 according to the scheme of digesta exchange. A part of this ${ }^{15} \mathrm{~N}$ disappeared during passage through this intestinal section that represents the absorption of endogenous $\mathrm{N}$. The rest of the ${ }^{15} \mathrm{~N}$ consisted of undigested residue of endogenous $\mathrm{N}$ in the ileal digesta. Thereby the ${ }^{15} \mathrm{~N}$ disappearance rate and ${ }^{15} \mathrm{~N}$ residue rate refers to the endogenous ${ }^{15} \mathrm{~N}$ in digesta, which represents the non-microbial ${ }^{15} \mathrm{~N}$ in digesta (see Equation 3). The $\mathrm{N}$ in bile and pancreas secretions was estimated as described by Sandek et al. (2001).

Endogenous $\mathrm{N}_{\text {ileum, animal No } 3}[\mathrm{~g} / \mathrm{d}]=$

(bile-pancreatic $\mathrm{N}[\mathrm{g} / \mathrm{d}]+$ endogenous $\left.\mathrm{N}_{\text {duod. }}[\mathrm{g} / \mathrm{d}]\right) \times \frac{\text { endogenous }{ }^{15} \mathrm{~N}_{\text {ileum }}[\mathrm{g} / \mathrm{d}]}{\text { endogenous }{ }^{15} \mathrm{~N}_{\text {duod. }}[\mathrm{g} / \mathrm{d}]}$ 
The sum of secreted endogenous $N$ (calculated on animal No. 1 by Equation 6) and of the undigested residues of endogenous $\mathrm{N}$ (calculated on animal No. 3 by Equation 7) gives the total endogenous $\mathrm{N}$ flow through the ileum (Table 2). This shows again the necessity of digesta exchange between labelled and unlabelled animals. In contrast to other methods, the digesta exchange between labelled and unlabelled animals enables not only the estimation of $\mathrm{N}$ secretion or $\mathrm{N}$ reabsorption during the digesta passage through a section of the intestinal tract, but it allows both to be determined in one experiment. This gives an advantage over other methods.

Excretion rate of endogenous $N$ in faeces. The value of endogenous $\mathrm{N}$ excretion in faeces was based on the calculation of endogenous $N$ flow through the ileum using animal No. 1. For the calculation of Net $\mathrm{N}$ secretion from the ileum to rectum, the removal of $3 \%$ duodenal and $3 \%$ ileal digesta was accounted for by a correction factor of 1.06. The calculated excretion rates of endogenous $\mathrm{N}$ in faeces are shown in Table 2.

Undegraded $N$ flow into the duodenum and ileum. The rumen undegraded $\mathrm{N}$ (UDN), which is the unfermented exogenous $N$, was calculated by subtraction of microbial $\mathrm{N}$ and endogenous $\mathrm{N}$ from the NAN at the duodenum and at the ileum.

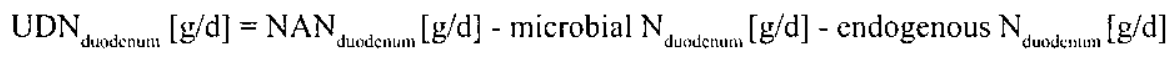

$$
\begin{aligned}
& \mathrm{UDN}_{\text {ileurn }}[g / d]=\left(\mathrm{NAN}_{\mathrm{ilcum}}[\mathrm{g} / \mathrm{d}]-\text { microbial } \mathrm{N}_{\text {ileum }}[\mathrm{g} / \mathrm{d}]\right) \times 1.03-\text { endogenous } \mathrm{N}_{\mathrm{ileum}}[\mathrm{g} / \mathrm{d}]
\end{aligned}
$$

The calculated values for the UDN and the other $\mathrm{N}$-fractions at the duodenum and at the ileum are summarized in Table 2.

\section{RESULTS}

\section{Passage of microbial $N$}

The microbial flow rate into the duodenum varicd from 3.3 to $7.2 \mathrm{~g} \mathrm{~N} / \mathrm{d}$ (44 to $58 \%$ of NAN flux). This was on average $5.8 \mathrm{~g} \mathrm{~N} / \mathrm{d}(50 \%$ of the NAN flow) in Group 1 and $5.1 \mathrm{~g} \mathrm{~N} / \mathrm{d}$ ( $46 \%$ of the NAN flow) in Group 2, respectively (Table 2). At the ileum the values varied from 0.6 to $1.9 \mathrm{~g} \mathrm{~N} / \mathrm{d}$ ( 16 to $29 \%$ of NAN flux). This was on average $0.9 \mathrm{~g} \mathrm{~N} / \mathrm{d}$ (19\% of the NAN flow) in Group 1 and $1.3 \mathrm{~g} \mathrm{~N} / \mathrm{d}(22 \%$ of the NAN flow) in Group 2, respectively.

Flow rates of endogenous $N$ and rumen undegraded $N$ at the duodenum and the ileum and excretion rates in faeces

The endogenous NAN flux into the duodenum, including the abomasal secretion and the epithelial cells sloughed from mouth, oesophagus and rumen, was 
small for Group $1(0.40 \mathrm{~g} \mathrm{~N} / \mathrm{d}=3.4 \%$ of NAN). For Group 2 with the higher CF but lower $\mathrm{N}$ intake it was much higher $(1.3 \mathrm{~g} / \mathrm{d}=12 \%$ of $\mathrm{NAN})$, and this required an adjustment for total $\mathrm{N}$ flow into the duodenum.

At the ileum the flow rates $(\mathrm{g} / \mathrm{d})$ of $\mathrm{N}, \mathrm{NAN}$ and also of endogenous $\mathrm{N}$ tended to be increased for Group 2, but in relation to total NAN the endogenous N proportion was nearly identical for both groups (34 vs $36 \%$ ).

The endogenous $\mathrm{N}$ excretion in faeces was highly variable $(1.84-2.39 \mathrm{~g} \mathrm{~N} / \mathrm{d}$ for Group 1; $1.54-2.00 \mathrm{~g} \mathrm{~N} / \mathrm{d}$ for Group 2). Relative to total $\mathrm{N}$ in faeces, the endogenous fraction was for Group $1-56 \%$ and for Group $2-40 \%$.

For all experiments the proportion of total $\mathrm{N}$ represented by the endogenous fraction increased from duodenum to ileum to faeces. For Group 1 the endogenous $\mathrm{N}$ excretion by faeces was higher than the endogenous $\mathrm{N}$ passage at the terminal ilcum $(129 \%)$ in contrast to Group 2, where it averaged only to $80 \%$ of the endogenous $\mathrm{N}$ passing the ileum.

The proportion of undegraded N from NAN in the duodenal and ileal digesta amounted to $46 \%$ of the NAN for Group 1 and to $41 \%$ for Group 2 . There were no differences between the duodenum and ileum.

\section{DISCUSSION}

The aim of the present experiments was to estimate the passage of postruminal $\mathrm{N}$ secreted in digesta in different segments of intestinal tract. To achieve this it was necessary to determine $\mathrm{N}$ and ${ }^{15} \mathrm{~N}$ passage rates and also that of microbial $\mathrm{N}$ and $\mathrm{NH}_{3}-\mathrm{N}$. Additionally the dietary $\mathrm{N}$ undegraded in the rumen was calculated as the difference between the flow rates of NAN, endogenous $\mathrm{N}$ and microbial $\mathrm{N}$ at the duodenum and ileum.

The microbial $\mathrm{N}$ flow at the duodenum amounted to about $50 \%$ of the NAN (Group 1) and $46 \%$ of the NAN (Group 2), respectively. In the ileum this fraction was only 19 to $22 \%$ of the NAN, demonstrating the high digestibility of microbial $\mathrm{N}$, on average $77 \%$. This value is in agreement with numerous data from literature (Tas et al.,1981; Storm et al., 1983; Hvelplund, 1985).

The endogenous NAN flow into the duodenum was low for Group $1(0.40 \mathrm{~g}$ $\mathrm{N} / \mathrm{d}=3.4 \%$ of NAN or $0.13 \%$ of $\mathrm{DM}$ ) but for Group 2 it was remarkably higher $(1.3 \mathrm{gN} / \mathrm{d}=12 \%$ of NAN or $0.4 \%$ of DM) (Sandek et al., 2001). The higher values of endogenous NAN flow into the proximal duodenum for Group 2 may be caused by the higher CF content in the dict of this group. This higher CF content gives rise to enhanced sloughing of epithelial cells and therefore to a higher endogenous NAN flux into the duodenum. Recently, Lammers-Wienhoven et al. (1998) demonstrated in sheep that the flow of endogenous $\mathrm{N}$ into the duodenum increased from 20 to $28 \%$ of total $\mathrm{N}$ flow if the dietary NDF content was increased from 15 to $68 \%$. 
The endogenous $\mathrm{N}$ flux for Group 2 ( $12 \%$ of NAN, which corresponds to $2.8 \mathrm{~g}$ / $\mathrm{kg} \mathrm{DM}$ intake and $4.0 \mathrm{~g} / \mathrm{kg}$ DM flow into the duodenum) is comparable to the results of Kaufmann and Hagemeister (1976), who calculated the endogenous protein $\mathrm{N}$-flux including bile and pancreas secretions into duodenum to be 10 to $15 \%$ of the protein $\mathrm{N}$ at the duodenum.

The endogenous $\mathrm{N}$ flux/DM intake calculated for Group 2 agrees with results of Harrop (1974), who calculated an endogenous $\mathrm{N}$ flux into the duodenum of $2.6 \mathrm{~g} / \mathrm{kg}$ DM intake. Recently experiments of Voigt et al. (1996) and Van Bruchem et al. (1997) using intra-abosomal ${ }^{15} \mathrm{~N}$ infusion to multifistulated sheep resulted in an average of $3.1 \mathrm{~g}$ endogenous $\mathrm{N}$ at the proximal duodenum, which is $12 \%$ of the total $\mathrm{N}$ flux at the duodenum and corresponds to $2.8 \mathrm{~g} / \mathrm{kg}$ DM intake. Lammers-Wienhoven et al. (1998) who used the same method estimated a higher value: 4.3 g endogenous $\mathrm{N}$, equivalent to $15 \%$ of total $\mathrm{N}$ flux at the duodenum or $4.2 \mathrm{~g} / \mathrm{kg}$ DM intake. Brandt et al. (1980) estimated, by the use of intraruminal ${ }^{15} \mathrm{~N}$ infusion, similar values in dairy cows $(3.6 \mathrm{~g}$ endogenous protein $\mathrm{N} / \mathrm{kg} \mathrm{DM}$ passage at the proximal duodenum or $9-12 \%$ of NAN flow). However, these values include secretions from bile and pancreas. In contrast to the good agreement of the results of Group 2 with data from the literature, the values for endogenous $\mathrm{N}$ flow into the duodenum in Group 1 are very small. The reason for this is not clear.

The endogenous $\mathrm{N}$ flow into the ileum increased during the passage from duodenum to ileum both absolutely and relatively ( $\%$ of NAN) (Table 2). At duodenum the amount of endogenous $\mathrm{N}$ flowing into the ileum was higher in Group 2 in comparison to Group 1. This may arise from the higher CF content in the ration of this group. This assumption is confirmed by experiments on sheep fitted with intestinal loops (Żebrowska and Kowalczyk, 1991). These authors found an increase of about $38 \%$ for total $\mathrm{N}$ secretion but no change for urea secretion, if Krebs-Ringer buffer was supplemented by cellulose into the loops. They suppose that the cellulose is responsible for the enhancement of the loss of mucosa cells in the intestinal tract and for the increase in production of brush border enzymes and mucosal proteins. Lammers-Wienhoven et al. (1998) found in sheep that the ileal endogenous $\mathrm{N}$ flow is positively related to the small intestinal NDF flow.

The increase in endogenous $\mathrm{N}$ from the duodenum to the ileum is caused by continuous $\mathrm{N}$ secretion during passage through the intestinal tract (Ben-Ghedalia et al., 1974; Van Bruchem et al., 1989; Lebzien and Rohr, 1994).

In contrast to the absolute values for endogenous $\mathrm{N}$, their proportion of total $\mathrm{N}$ flow into the ileum did not differ between the feeding groups, which is in agreement with the results of Bergner et al. (1994). The values of $34 \%$ (Group 1) and $36 \%$ (Group 2) are similar to those of Lebzien and Rohr (1994), who estimated that at the ileum of cows, the endogenous $\mathrm{N}$ portion was $40 \%$ of the total amino 
acid N. Voigt et al. (1996), Van Bruchem et al. (1997) and Lammers-Wienhoven et al. (1998) estimated a higher endogenous proportion of total $\mathrm{N}(48 \%)$ for 55 $\mathrm{kg}$ sheep. According to Van Bruchem et al. $(1985,1989)$ and Oosting et al. (1995) $50-75 \%$ of ileal $\mathrm{N}$ is of endogenous origin. Their experiments were carried out on $60-70 \mathrm{~kg}$ sheep. The smaller endogenous $\mathrm{N}$ part in the present experiments may be caused by the lower liveweight associated with lower DM intake and DM passage through the intestinal tract.

The endogenous $\mathrm{N}$ excretion in faeces is of interest, because a quantitative estimate of it is necessary for calculation of true $\mathrm{N}$ digestibility. The excretion rates of endogenous $\mathrm{N}$ in faeces varied highly for the individual experiments (1.84 to $2.39 \mathrm{~g} \mathrm{~N} / \mathrm{d}$ for Group 1; 1.54 to $2.00 \mathrm{~g} \mathrm{~N} / \mathrm{d}$ for Group 2). Because of this high variance no significant differences for this $\mathrm{N}$ fraction were found between the 2 treatments.

Referring to DM intake the mean faecal endogenous $\mathrm{N}$ excretion was $3.4 \mathrm{~g} / \mathrm{kg}$ (Group 1) and $3.7 \mathrm{~g} / \mathrm{kg}$ (Group 2). This was slightly lower than the values estimated by Voigt et al. (1996) and Van Bruchem et al. (1997) which amounted to $4.5 \mathrm{~g} / \mathrm{kg}$ DM intake. The endogenous $\mathrm{N}$ in faeces is mainly composed of endogenous microbial N (Ørskov and MacLeod, 1982). The non-microbial endogenous $\mathrm{N}$ (abraded epithelial cells, enzymes and mucoproteins), the true endogenous $\mathrm{N}$ (Ørskov, 1992), represents only a small part of the endogenous $\mathrm{N}$ fraction in faeces (Mason, 1969; Dixon and Nolan, 1983).

Relative to total $\mathrm{N}$, faecal endogenous $\mathrm{N}$ amounted to $56 \%$ (Group 1) and $40 \%$ (Group 2) demonstrating that large amounts of faecal $\mathrm{N}$ are of endogenous source. These values are similar to those (51-55\%) of Van Bruchem et al. (1997) and Lammers-Wienhoven et al. (1998). With regards to dietary effects Lammers-Wienhoven et al. (1998) found that its high influence was leading to values which varied from 43 to $76 \%$. During all experiments the proportion of endogenous $\mathrm{N}$ increased from the duodenum to ileum to faeces. That means that $\mathrm{N}$ secretion must be higher than $\mathrm{N}$ absorption.

Caution is required in the interpretation of endogenous $\mathrm{N}$ flow and excretion, because only one precursor pool was used for all endogenous $\mathrm{N}$ fractions (bile and pancreas $\mathrm{N}$, abraded epithelial cells, mucoproteins, urea), whereas it is likely that the endogenous $\mathrm{N}$ in the gut lumen derives from multiple precursor pools (Moughan et al., 1992). The most used and best suited precursor for endogenous $\mathrm{N}$ is the TCA soluble fraction of blood plasma (Souffrant et al., 1993; Krawielitzki et al., 1990; Van Leeuwen et al., 1994; Voigt et al., 1996; LammersWienhoven et al., 1998), which was chosen also in the present experiments. This, however, is a simplification, which can lead to endogenous $N$ values being either overestimated (Souffrant et al., 1993; Lien et al., 1997; Leterme et al., 1998) or underestimated (Souffrant et al., 1986; Moughan et al., 1998). Despite these reservations, the ${ }^{15} \mathrm{~N}$ dilution method is potentially useful for studying the factors that 
influence the secretion of endogenous N (Souffrant et al., 1986; Moughan et al., 1998). Further studies are needed, however, to refine the methodology for estimating endogenous $\mathrm{N}$.

\section{REFERENCES}

Ben-Ghedalia D., Tagari, H., Bondi A., Tadmor A., 1974. Protein digestion in the intestine of sheep. Brit. J. Nutr. 31, 125-142

Bergner H., Drochner W., Bartelt J., 1994. Secretion of endogenous protein in dependence of the protein and fibre intake of ${ }^{15} \mathrm{~N}$-labelled pigs. Proceedings of $6^{\text {th }}$ International Symposium on Digestive Physiology in Pigs, Bad Doberan (Germany). EAAP Publication No 80, Vol. I, 11-13

Brandt M., Rohr K., Lebzien P., 1980. Bestimmung des endogenen Protein-N im Duodenalchymus von Milchkühen mit Hilfe von ${ }^{15} \mathrm{~N}$. Z. Tierphysiol. Tierernähr. Futtermittelk. 44, 26

Dixon R.M., Nolan J.V., 1983. Studies of the large intestine of sheep. 3. Nitrogen kinetics in sheep given chopped lucerne (Medicago sativa) hay. Brit. J. Nutr. 50, 757-768

Harrop C.J.F., 1974. Nitrogen metabolism in the ovine stomach. 4. Nitrogen compounds of the abomasal secretions. J. Agr. Sci. 83, 249-257

Hvelplund T., 1985. Digestibility of rumen microbial protein and undegraded dietary protein estimated in the small intestine of sheep and by in sacco procedure. Acta Agr. Scand., Suppl. 25, $132-144$

Kaufmann W., Hagemeister H., 1976. Zum Einfluß der Behandlung mit Formaldehyd auf die baktericlle Protcinsynthese und die Abbaurate von Protein in den Vormägen von Milchkühen sowie die Verdaulichkeit des Proteins im Darm. Kieler Milchwirtschaftl. Forschungsberichte 28 (3), 335 346

Krawielitzki K., Żebrowska T., Schadereit R., Kowalczyk J., Hennig U., Wünsche J., H.frrmann U., 1990. Determining of nitrogen absorption and nitrogen secretion in different sections of the pig's intestine by digesta exchange between ${ }^{15} \mathrm{~N}$ labelled and unlabelled animals. Arch. Anim. Nutr. 40, 25-37

Lammers-Wienhoven S.C.W., Voigt J., Ram L., Van Bruchem J., Ketclaars J., Tamminga S., 1998. Effect of cell walts, dry matter and protein supply on endogenous nitrogen flow in the small intestine of sheep. J. Anim. Physiol. Anim. Nutr. 79, 225-236

Lebzien P., Rohr K., 1994. Bestimmung der wahren Verdaulichkeit von Aminosäuren aus dem Dünndarm von Milchkühen. Arch. Anim. Nutr. 45, 355-362

Leterme P., Seve B., Thewis A., 1998. The current N-15-leucine infusion technique is not suitable for quantitative measurements of ileal endogenous amino acid flows in pigs. J. Nutr: 128, 19611968

Lien K.A., Saucr W.C., Mosenthin R., Souffrant W.-B., Dugan M.E.R., 1997. Evaluation of the ${ }^{15} \mathrm{~N}$-isotope dilution technique for determining the recovery of endogenous protein in ileal digestion of pigs: Effect of difution in the precursor pool for endogenous nitrogen secretion. J. Anim. Sci. 75, 148-158

Mason V.C., 1969. Some observations on the distribution and origin of nitrogen in shecp facces. J. Agr. Sci. 73, 99-111

Moughan P.J., Buttery P.J., Essex C.P., Soar J.B., 1992. Evaluation of the isotope dilution technique for determining ileal endogenous nitrogen excretion in the rat. J. Sci. Food Agr. 58, 165-172 
Moughan P.J., Souffrant W.-B., Hodgkinson S.M., 1998. Physiological approaches to determining gut endogenous amino acid flows in the mammal. Arch. Anim. Nutr. 51, 237-252

Oosting S.J., Van Bruchem J., Chen X.B., 1995. Intake, digestion and small intestinal protein availability in sheep in relation to ammoniation of wheat straw with or without protein supplementation. Brit. J. Nutr. 74, 347-368

Ørskov E.R., 1992. Protein Nutrition in Ruminants. Academic Press, London, pp. 94-104

Ørskov E.R., MacLeod N.A., 1982. The determination of the minimal nitrogen excretion in steers and dairy cows and its physiological and practical implications. Brit. J. Nutr. 47, 625-636

Sandek A., Krawielitzki K., Kowalczyk J., Kreienbring F., Gabel M., Żebrowska T., Voigt J., 2001. Studies on $\mathrm{N}$-metabolism in different gastrointestinal sections of sheep using the digesta exchange technique. 1. Model and experimental conditions. J. Anim. Feed Sci. 10, 421-434

Schönhusen U., Voigt J., Piatkowski B., 1988. Untersuchungen zur Nutzung von Ribonukleinsäure als Marker für die Messung des mikrobiellen Proteinertrages im Pansen. 1. Chemische Bestimmung von Ribonukleinsäure. Arch. Anim. Nutr. 38, 289-297

Souffrant W.-B., Rerat A., Laplace J.P., Darcy-Vrillon B., Köhler R., Corring T., Gebhardt G., 1993. Exogenous and endogenous contributions to the nitrogen fluxes in the digestive tract of pigs fed a casein diet. 3. Recycling of endogenous nitrogen. Reprod. Nutr. Develop. 33, 373-382

Storm E., Brown D.S., Ørskov E.R., 1983. The nutritive value of rumen microorganisms in ruminants. 2. The apparent digestibility and net utilization of microbial $\mathrm{N}$ for growing lambs. Brit. J. Nutr. 50, 471-478

Tas M.V., Evans R.A., Axford R.F.E.,1981. The digestibility of amino acids in the small intestine of sheep. Brit. J. Nutr. 45, 167-174

Van Bruchem J., Bongers L.J.G.M., van Walsem J.D., Onck W., van Andrichem P.W.M., 1985. Digestion of proteins of varying degradability in sheep. 3. Apparent and true digestibility in the small intestine and ileal endogenous loss of $\mathrm{N}$ and amino acids. Neth. J. Agr. Sci. 33, 285-295

Van Bruchem J., Bongers L.J.G.M., Lammers-Wienhoven S.C.W., Bangma G.A., Van Adrichem P.M.W., 1989. Apparent and true digestibility of protein and amino acids in the small intestine of sheep as related to duodenal passage of protein and non-protein dry-matter. Livest. Prod. Sci. 23, 317-327

Van Bruchem J., Voigt J., Lammers-Wienhoven T.S.C.W., Schönhusen U., Ketelaars J.J.M.H., Tamminga S., 1997. Secretion and reabsorption of endogenous protein along the small intestine of sheep: estimates derived from ${ }^{15} \mathrm{~N}$-dilution of plasma non-protein N. Brit. J. Nutr. 77, 273-286

Van Leeuwen P., Van de Berg J.W.O., Schulze H., Jansman A.J.M., Verstegen M.W.A., Deuring K., 1994. Methodological aspects of the ${ }^{15} \mathrm{~N}$ dilution technique to study endogenous $\mathrm{N}$ in ileal digesta of pigs. Proceedings of $6^{\text {th }}$ International Symposium on Digestive Physiology in Pigs, Bad Doberan (Germany). EAAP Publication No 80, Vol. I, 8-10

Voigt J., Steger H., 1967. Zur quantitativen Bestimmung von Ammoniak, Harnstoff und Ketokörpern in biologischem Material mit Hilfe eines modifiziertem Mikrodiffusionsgefässes. Arch. Tierernähr. $17,289-293$

Voigt J., Van Bruchem J., Krawielitzki K., Lammers-Wienhoven T.S.C.W., Schönhusen U., Tamminga S., Hagemeister H., 1996. Untersuchungen zum Recycling von Stickstoff beim Schaf. Výskumný Ústav Živočisnej Výroby, Ústav Vyzivy Zvierat (VUZV), Nitra Press, pp. 15-21

Żebrowska T., Kowalczyk J., 1991. Nitrogen secretion into isolated loops of the small intestine in conscious sheep. J. Anim. Physiol. Anim. Nutr. 65, 133-139 
Badania nad przemianą azotu w różnych odcinkach przewodu pokarmowego owiec przy zas-
tosowaniu metody „wymiany treści”. 2. Przeplyw azotu endogennego

W doświadczeniach, przeprowadzonych na dwóch grupach rosnących owiec z przetokami do różnych odcinków przewodu pokarmowego, badano wpływ zawartości włókna w dawce pokarmowej na tempo przepływu azotu endogennego wydzielanego do poszczególnych odcinków przewodu pokarmowego. Do badań zastosowano metodę wymiany treści przepływającej przez przewód pokarmowy zwierząt znakowanych i nie znakowanych ${ }^{15} \mathrm{~N}$. Owce otrzymywały dawki pokarmowe zawierające około $16 \%$ białka ogólnego w suchej masie i różniące się zawartością włókna surowego: $14,7 \%$ w Grupie I i $24,9 \%$ w Grupie II.

Przepływ azotu ogólnego i ${ }^{15} \mathrm{~N}$ przez dwunastnicę $\mathrm{i}$ jelito biodrowe oraz ich wydalanie w kale i moczu mierzono bezpośrednio, a otrzymane wartości użyto do obliczenia przepływu azotu wydzielanego w różnych odcinkach jelita. Przepływ azotu drobnoustrojów przez początkowy odcinek dwunastnicy i końcowy odcinek jelita biodrowego obliczono na podstawie przepływu RNA przez dwunastnicę i jelito biodrowe oraz stosunek N:RNA w bakteriach izolowanych z płynu żwaczowego. Ilość $\mathrm{N}$ endogennego w treści dwunastnicy i jelita biodrowego oraz wydalonego w kale oznaczono na podstawie wzrostu lub obniżenia ilości ${ }^{15} \mathrm{~N}$ w treści odpowiednich odcinków jelita zwierząt nie znakowanych otrzymujących ${ }^{15} \mathrm{~N}$ z treścią lub zwierząt znakowanych otrzymujących treść od zwierząt nie znakowanych.

Ilość azotu bakteryjnego przepływającego przez dwunastnicę wynosiła średnio $5,8 \mathrm{~g} / \mathrm{d}$ w Grupie 1 i $5,1 \mathrm{~g} / \mathrm{d}$ w Grupie 2 ( 50 do $46 \%$ NAN), a przeplywającego przez jelito biodrowe $0,9 \mathrm{~g} / \mathrm{d}$ w Grupie 1 i $1,3 \mathrm{~g} / \mathrm{d}$ w Grupie 2 ( 19 do $22 \%$ NAN). Udział N białka nie rozłożonego w żwaczu w NAN przepływającym przez dwunastnicę i jelito biodrowe stanowił $46 \%$ w Grupie 1 i $41 \%$ w Grupie 2. Ilość NAN pochodzenia endogennego przepływająca do dwunastnicy była niska w Grupie $1(0,40 \mathrm{~g} \mathrm{~N} / \mathrm{d}=3,4 \%$ NAN) i około trzy razy większa w Grupie $2(1,3 \mathrm{~g} \mathrm{~N} / \mathrm{d}=12 \% \mathrm{NAN})$. Odpowiednie ilości N endogennego w jelicie biodrowym wynosiły 1,6 g/d (34\% NAN) i 2,2 g N/d (36\% NAN), co wskazuje że sekrecja $\mathrm{N}$ endogennego w tym odcinku przewodu pokarmowego, wyrażona we względnych wartościach, była niezależna od rodzaju skarmianej dawki.

Wydalanie azotu w kale różniło się w poszczególnych doświadczeniach $(1,84$ to $2,39 \mathrm{~g} \mathrm{~N} / \mathrm{d}$ w Grupie 1; 1,54 do 2,00 g N/d w Grupie 2). Udział N endogennego w stosunku do $\mathrm{N}$ ogólnego wydalanego w kale był większy w Grupie 1 (56 \%) niż w Grupie 2 (40\%).

We wszystkich doświadczeniach udział $\mathrm{N}$ endogennego w $\mathrm{N}$ ogólnym treści zwiększał się od dwunastnicy do rectum. Mimo pewnych zastrzeżeń do metody rozcieńczenia ${ }^{15} \mathrm{~N}$, jej zastosowanie w połączeniu z techniką wymiany treści między znakowanymi i nie znakowanymi zwierzętami może być przydatne do ilościowego określania sekrecji $\mathrm{N}$ w jelitach w zależności od czynników żywieniowych. Potrzebne są dalsze badania nad udoskonaleniem tej metody. 